\section{Summary}

The results of isolation and serological tests for human A2 viruses among swine, cattle, poultry, dogs, cats, and horses before and after an epidemic in Ireland are presented.

There was no evidence for the presence of either Shope or A2 virus among swine. The results for cattle were also uniformly negative.

Cats, dogs, and poultry show a small number of positives with A2/Asia/ 57 virus. Reasons are given for regarding the positive results as non-specific.

Among horses $\mathrm{A} /$ equi/Praha virus, or one closely related to it, may be present, but no epizootic due to it has been described and no strains of it have been isolated. Positive results with A2/Asia/57 and A2/
Eire/8/61 were obtained, but none with A2/Asia/57 (Ashton) or A2/Singapore/W/1/57. Technical and epidemiological reasons are given for regarding the positive results as non-specific.

It is concluded that there is no reservoir of A2 viruses in animals in Ireland, and that no spread to them occurred during the January, 1961 epidemic.

This investigation was supported by Grant No. E-2733 from the National Institutes of Health, American Public Health Service.

\section{REFERENCES}

Kaplan, M. M., and Payne, A. M-M. (1959). Bull. Wld Hlth Org., $20,465$.

Meenan, P. N., and Boyd, M. R. (1962). Lancet, 1, 96.

Schaefter, M., and Robinson, R. Q. (1961). Amer. Rev. resp. Dis. 83, Pt. 2, 47.

World Health Organization (1953). Techn. Rep. Ser., No. 64.

\title{
ABO BLOOD GROUPS AND ACUTE RESPIRATORY VIRUS DISEASE
}

\author{
J. C. McDONALD, M.D., M.Sc., D.P.H. \\ Flight Lieutenant, Royal Air \\ Force*
}

Acute respiratory virus infections are responsible for many deaths before and during reproductive life and some effect might therefore be expected on natural selection. It seemed possible that the inheritance of any natural resistance to these diseases would be related to blood groups or other inherited characteristics.

Surveys of acute respiratory illness have been carried out jointly by the Directorate of Hygiene and Research of the Royal Air Force and the Public Health Laboratory Service since 1954. In the course of this work a large number of men admitted to sick quarters with a

\section{A. J. ZUCKERMAN, M.B., D.Obst.R.C.O.G., B.Sc. Epidemiological Research Laboratory, Colindale, London}

100 patients and 52 had been born outside the British Isles, leaving 1,875 available for study.

The distribution of blood groups to serve as a control was kindly supplied by Dr. A. C. Kopéc, of the Nuffield Blood Group Centre, from a sample of 47,108 R.A.F. recruits, also born in the British Isles, who had been tested during the period of our own surveys, 1956-61. The results of this sample, divided into three regional groups according to the recruit's place of birth, are shown in Table I. Counties south of a line from the Wash to the Severn were included in region 1 , the

TABLE I.-Distribution of Blood Groups in 47,108 R.A.F. Recruits, 1956-61*

\begin{tabular}{|c|c|c|c|c|c|}
\hline Place of Birth & No. Tested & Group O & Group A & Group B & Group AB \\
\hline $\begin{array}{l}\text { Region } 1 \text { (S. England) } \\
\quad, \quad 2 \text { (N. England, Wales, and s. W. Scotland) } \\
\quad, \quad 3 \text { (rest of the British Isles) } \ldots\end{array}$ & $\begin{array}{r}21,134 \\
20,043 \\
5,931\end{array}$ & $\begin{array}{l}9,244(43 \cdot 7 \%) \\
9,456(47 \cdot 2 \%) \\
2,994(50 \cdot 5 \%)\end{array}$ & $\begin{array}{l}9,556(45 \cdot 2 \%) \\
8,265(41 \cdot 2 \%) \\
2,095(35 \cdot 3 \%)\end{array}$ & $\begin{array}{l}1,700(8 \cdot 0 \%) \\
1,725(8 \cdot 6 \%) \\
646(10 \cdot 9 \%)\end{array}$ & $\begin{array}{l}634(3 \cdot 0 \%) \\
597(3.0 \%) \\
196(3 \cdot 3 \%)\end{array}$ \\
\hline
\end{tabular}

* Supplied by Dr. A. C. Kopéc, of the Nuffield Blood Group Centre.

respiratory illness were investigated virologically and the causal infection was identified. Since 1956 all recruits to the Royal Air Force have been tested for blood group on entry, and this, together with such other information as place of birth, colour of eyes, hair, and skin, and colour perception, has been recorded in their personal documents. The means were thus available for an investigation of this problem and a unique opportunity was afforded by the appearance in 1957 of the influenza $\mathrm{A} 2$ group of viruses which the population had not encountered previously. This could not be said for most of the other virus groups-adenovirus in particular-to which the men had been exposed for many years.

\section{Materials and Methods}

Information was taken from the records held by the Air Ministry of just over 2,000 persons admitted since 1956 to station sick quarters with a respiratory illness associated with one or more identified virus infections. Only diagnoses based on virus isolation or a fourfold or greater rise in antibody titre were accepted. The great majority of the patients were new recruits, mostly 18-20 years of age. Records were incomplete in about

*Attached to the Epidemiological Research Laboratory. remaining counties of England and Wales and four in South-west Scotland in region 2, and the rest of Scotland and Ireland in region 3.

\section{Results}

The distribution of blood groups in 1,685 patients in five main diagnostic categories is shown in Table II, which does not include 152 patients with evidence of

TABLE II.-Distribution of Blood Groups in 1,685 Patients with Selected Respiratory Virus Diseases

\begin{tabular}{|c|c|c|c|c|c|c|}
\hline Infection & $\begin{array}{c}\text { Region } \\
\text { of Birth }\end{array}$ & $\begin{array}{l}\text { No. of } \\
\text { Patients }\end{array}$ & $\begin{array}{c}\text { Group } \\
\text { O }\end{array}$ & $\underset{\mathbf{A}}{\text { Group }}$ & $\underset{\text { B }}{\text { Group }}$ & $\underset{A B}{\text { Group }}$ \\
\hline $\begin{array}{c}\text { Influenza } \\
\text { A1 }\end{array}$ & $\begin{array}{l}1 \\
2 \\
3\end{array}$ & $\begin{array}{l}69 \\
45 \\
15\end{array}$ & $\begin{array}{r}33 \\
22 \\
8\end{array}$ & $\begin{array}{r}31 \\
17 \\
5\end{array}$ & $\begin{array}{l}4 \\
4 \\
1\end{array}$ & $\begin{array}{l}1 \\
2 \\
1\end{array}$ \\
\hline Influenza & $\begin{array}{l}1 \\
2 \\
3\end{array}$ & $\begin{array}{r}313 \\
316 \\
72\end{array}$ & $\begin{array}{r}171 \\
167 \\
46\end{array}$ & $\begin{array}{r}104 \\
111 \\
22\end{array}$ & $\begin{array}{r}31 \\
32 \\
3\end{array}$ & $\begin{array}{l}7 \\
6 \\
1\end{array}$ \\
\hline$\underset{B}{\text { Influenza }}$ & $\begin{array}{l}1 \\
2 \\
3\end{array}$ & $\begin{array}{r}32 \\
25 \\
6\end{array}$ & $\begin{array}{r}19 \\
8 \\
2\end{array}$ & $\begin{array}{r}9 \\
14 \\
4\end{array}$ & $\begin{array}{l}2 \\
2 \\
0\end{array}$ & $\begin{array}{l}2 \\
1 \\
0\end{array}$ \\
\hline $\begin{array}{c}\text { Adeno- } \\
\text { virus }\end{array}$ & $\begin{array}{l}1 \\
2 \\
3\end{array}$ & $\begin{array}{l}351 \\
211 \\
105\end{array}$ & $\begin{array}{r}134 \\
86 \\
48\end{array}$ & $\begin{array}{r}179 \\
92 \\
43\end{array}$ & $\begin{array}{r}29 \\
19 \\
9\end{array}$ & $\begin{array}{r}9 \\
14 \\
5\end{array}$ \\
\hline $\begin{array}{l}\text { Cox- } \\
\text { sackie } \\
\text { A21 }\end{array}$ & $\begin{array}{l}1 \\
2 \\
3\end{array}$ & $\begin{array}{l}52 \\
58 \\
15\end{array}$ & $\begin{array}{r}29 \\
29 \\
9\end{array}$ & $\begin{array}{r}19 \\
27 \\
5\end{array}$ & $\begin{array}{l}3 \\
2 \\
1\end{array}$ & $\begin{array}{l}1 \\
0 \\
0\end{array}$ \\
\hline
\end{tabular}


more than one virus infection and 38 with para-influenza or influenza $\mathrm{C}$ infections. The observed percentage of patients in each blood group and the expected proportions calculated from the control figures, making due allowance for the regional constitution of the observed group, are shown in Table III. There was a considerable

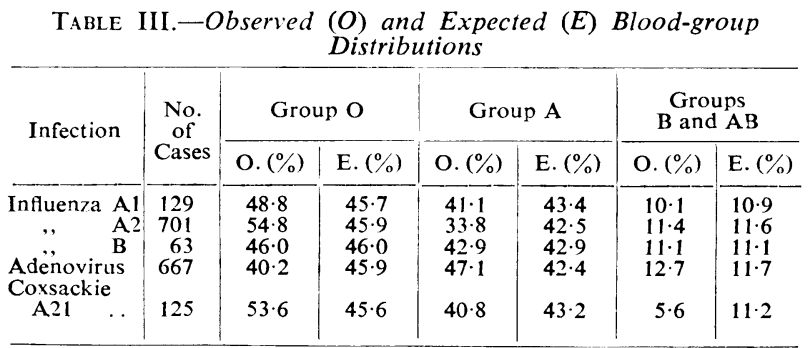

excess of group $\mathrm{O}$ patients and corresponding deficiency of group $A$ in the influenza A2 infections. The influenza $A 1$, influenza $B$, and Coxsackie A21 (Coe virus) infections did not differ greatly from expectation, but the adenovirus group showed an opposite trend from the influenza A2 infections but of lesser degree. The statistical significance of the differences between the distributions for controls in Table I and of patients in Table II was tested by the method of Woolf (1955). For influenza A2 the difference was highly significant $\left(\chi^{2}=22.9 ; \mathrm{P}<0.00001\right)$ and for the adenovirus illnesses it was moderately so $\left(\chi^{2}=8.0 ; \mathrm{P}<0.005\right)$. With influenza $\mathrm{A} 1$, influenza $\mathrm{B}$, and Coxsackie A21 infections the observed values were close to those expected $(\mathrm{P}>0.5$ in all three). The deviations of both the influenza A2 and adenovirus infections were almost equally present in all three geographical regions. The $\chi^{2}$ value for heterogeneity was $2.2(\mathrm{P}=0.33)$ for the $\mathrm{A} 2$ infections and $0.08(\mathrm{P}=0.96)$ for the adenovirus infections (Table IV).

TABLE IV.-Relative Incidence of Blood Groups $O$ and $A$ in Patients with Influenza $A 2$ and Adenovirus Infections by Geographical Region

\begin{tabular}{|c|c|c|c|c|c|c|}
\hline \multirow[b]{2}{*}{ Region } & \multicolumn{3}{|c|}{ Influenza A2 } & \multicolumn{3}{|c|}{ Adenovirus } \\
\hline & $\begin{array}{l}\text { No. in } \\
\text { Disease } \\
\text { Series }\end{array}$ & $\mid \begin{array}{c}\text { Relative } \\
\text { Incidence } \\
\mathrm{O}: \mathrm{A}\end{array}$ & $x^{2}$ & $\begin{array}{l}\text { No. in } \\
\text { Disease } \\
\text { Series }\end{array}$ & $\begin{array}{c}\text { Relative } \\
\text { Incidence } \\
\mathrm{A}: \mathrm{O}\end{array}$ & $x^{2}$ \\
\hline $\begin{array}{l}1 \\
2 \\
3\end{array}$ & $\begin{array}{r}313 \\
316 \\
72\end{array}$ & $\begin{array}{l}1.699 \\
1.315 \\
1.463\end{array}$ & $\begin{array}{r}17.929 \\
4.926 \\
2 \cdot 130\end{array}$ & $\begin{array}{l}351 \\
211 \\
105\end{array}$ & $\begin{array}{l}1.292 \\
1.224 \\
1.280\end{array}$ & $\begin{array}{l}4.955 \\
1.797 \\
1.359\end{array}$ \\
\hline Total & 701 & & & 667 & & \\
\hline \multirow[b]{2}{*}{$\psi^{2}$} & & Total & $\left(\begin{array}{c}24.985 \\
(\mathbf{P}<0.00001)\end{array}\right.$ & & Total & $\left(\begin{array}{c}8 \cdot 111 \\
(P<0.005)\end{array}\right)$ \\
\hline & \multicolumn{2}{|c|}{$\begin{array}{l}\text { Difference from } \\
\text { unity } \\
\text { D. of } F .=1 \\
\text { Heterogeneity } \\
\text { D. of } F .=2\end{array}$} & $\begin{array}{r}22 \cdot 869 \\
2 \cdot 196\end{array}$ & \multicolumn{2}{|c|}{$\begin{array}{l}\text { Difference from } \\
\text { unity } \\
D \text {. of } F .=1 \\
\text { Heterogeneity } \\
\text { D. of } F .=2\end{array}$} & $\begin{array}{l}8.027 \\
0.084\end{array}$ \\
\hline
\end{tabular}

The proportion Rh-negative in each diagnostic category showed only minor variations. The distributions of hair colour, eye colour, and colour perception were also examined in detail. There appeared to be no important differences between the diagnostic groups in any of these characteristics.

\section{Discussion}

The differential susceptibility of persons of blood groups $\mathrm{O}$ and $\mathrm{A}$ to plague and smallpox and the contribution that this may have made to the present-day world distribution of human $\mathrm{ABO}$ blood groups has been the subject of recent controversy between Pettenkofer et al. (1962) and Springer and Wiener (1962).
Support for the hypothesis of Pettenkofer and his colleagues has come from Harris et al. (1962), who also found evidence of an antigenic relationship between human blood-group A substance and vaccinia virus.

The past and present effects of influenza and other acute respiratory infections on natural selection are likely to have been at least as great as those of either plague or smallpox, and our findings again suggest an association with the blood-group system. Any advantage possessed by persons of blood group A against influenza A2 virus infection does not exclude the possibility that they might also have had a similar advantage against the other respiratory viruses in other circumstances. The A2 virus was new to the population whereas the other viruses were not. Even the apparent susceptibility of persons of blood group $A$ to adenovirus infections might have resulted from a failure to acquire antibody in childhood because of raised natural resistance. Adenovirus infection has a remarkable epidemiological pattern in recruit camps that is not fully understood (McDonald et al., 1958).

Our findings do not therefore indicate whether any natural resistance is of high or low specificity. If high, some immunological mechanism might be suspected, though there is no virological evidence, apart from that of Mulder (1957), of any antibody to A2 virus in the population before 1957, and this was found only in persons over 70 years of age. A natural resistance of low specificity could be explained by the presence of some inhibitory secretion, perhaps related to blood-group substance, in the respiratory mucosa.

\section{Summary}

The $\mathrm{ABO}$ and $\mathrm{Rh}$ blood-group distribution was studied in almost 2,000 persons admitted to sick quarters in the R.A.F. between 1956 and 1961 with a respiratory virus infection diagnosed serologically or by virus isolation.

There was a substantial relative excess of group $O$ patients and a corresponding deficiency of group $A$ among those infected with influenza A2 virus $(P<0.00001)$. An opposite trend of lesser degree was seen in the adenovirus infections $(P<0.005)$. The figures for influenza A1, influenza $B$, and Coxsackie A21 infections did not differ significantly from those expected.

The distribution of $\mathrm{Rh}$ genotypes, hair colour, eye colour, and colour perception was similar in all the diagnostic groups studied.

We are greatly indebted to Dr. A. C. Kopéc for allowing us to use for control purposes figures from an analysis of blood groups in R.A.F. recruits, to Wing Commander A. C. Camm for his help with medical records, and to Dr. J. A. Fraser Roberts for his advice and encouragement. We thank the Director-General of Medical Services, Royal Air Force, for granting facilities for this study and for permission to publish the results.

This study formed part of a thesis submitted by one of us (A.J.Z.) for the M.Sc. degree to the Department of Genetics, University of Birmingham.

\section{REFERENCES}

Harris, R., Harrison, G. A., and Rondle, C. J. M. (1962). Lancet, 1, 622 .

McDonald, J. C., Wilson, J. S., Thorburn, W. B., Holland, W. W., and Ändrews, B. E. (1958). Brit. med. J., 2, 721. Mulder, J." (1957). Lancet, 2, 334.

Pettenkofer, H. J., Stöss, B., Helmbold, W., and Vogel, F. (1962). Nature (Lond.), 193, 445.

Springer, G. F., and Wiener, A. S. (1962). Ibid., 93, 444.

Woolf, B. (1955). Ann. hum. Genet., 19, 251. 